\title{
Population and Labor Dynamics in Large Informal Markets: Implications for Pension Systems with Evidence from Ecuador
}

\author{
Margarita Velín-Fárez
}

ABSTRACT

KEY WORDS: $\quad$ Public pensions, Informality, Labor Markets, Latin America, Ecuador.

JEL Classification: H55, J08.

Instituto Universitario de Análisis Económico y Social (IAES), Universidad de Alcalá

\section{Introduction}

Population aging is accelerating in developed countries, particularly due to demographic trends (Peeters, 2012). In the Organization for Economic Co-operation and Development (OECD) countries, the total proportion of persons aged 65 and over population increased from around 10\% in 1960 to $16 \%$ in 2016 (being 26\% in Japan and 21\% in Italy) (Organisation for Economic Co-operation, 2016). This growing trend is expected to result in the proportion of persons aged 65 and over in the EU-27 amounting to $28.8 \%$ in 2050 , while in countries such as Italy, Spain, and Germany, it is expected to be

Correspondence concerning this article should be addressed to: Margarita Velín-Fárez, Instituto Universitario de Análisis Económico y Social (IAES), Universidad de Alcalá, Plaza de la Victoria, 2, 28802 Alcalá de Henares, Spain. E-mail: margarita.velin@edu.uah.es around 32\% (Conde-Ruiz \& González, 2010). This increase in the older population will also be seen in less developed countries, but at a more accelerated rate than in European countries. While population aging is creating significant problems for the financial sustainability of developed countries' pension systems, in Latin America these problems will be exacerbated by poorly developed pension systems with low coverage (Bosch et al., 2013; Filgueira \& Manzi, 2017; Organisation for Economic Co-operation, 2017). For this reason, the analysis of demographic dynamics and economic contexts in less developed countries is crucial to inform public debates within governments, academia, and international organizations, such as the World Bank (WB), International Monetary Fund (IMF), and the OECD, among others. 
Most pension systems worldwide are designed under a contributory principle. Hence, pension entitlements depend on employees' contributions during their working lives (i.e., they are earnings-based). Regardless of funding, coverage and pension benefits are determined by how many workers contribute to or save under the available pension schemes. Therefore, in countries with large informal employment sectors-associated with poor social security coverage (see International Labor Organization, 2013 and Bosch et al., 2013) — pension coverage and benefits are ultimately inadequate for most workers, while for others they provide high rates of return, leading to considerable inequality among pensioners. In addition to inequality concerns, pension systems in less developed countries cannot fulfill their four main objectives: consumption smoothing, longevity insurance, redistribution, and poverty prevention (see Blake, 2006).

Ecuador, a dollarized and small developing country located in South America-where the informal sector is large - has a pay-as-you-go (PAYG) pension system that provides coverage to a low percentage of the population. To understand its future prospects and propose an alternative for reform, analysis of the country's population dynamics as well as the characteristics and employment status of the working population is crucial. Such analysis can yield insights into the sources of pension systems' financial problems, population structure by age cohorts, the socioeconomic characteristics of informality that limit the coverage and adequacy of pension benefits (and determine inequalities among older adults), and the basis for proposing policy reforms.

This paper addresses these questions by analyzing the population and labor market dynamics and their interlinkages with the Ecuadorian pension system. Some studies have dealt with similar issues, notably Melguizo et al. (2017), who reviewed the current state of labor markets in Latin America and the Caribbean (LAC) countries. We also use administrative data, and our analysis is conducted according to age groups, gender, inequalities, and the characteristics of informality, providing a more detailed analysis of the Ecuadorian case. We believe that this will provide a useful tool for policy discussions and evaluations in other Latin American countries (even in European ones with either earnings-related PAYG schemes or similar economic characteristics) about structural and parametric reforms in pension systems and labor market institutions. For example, Spain has similar rules for its PAYG pension system but has an older population. Poland, like Ecuador, has a high degree of shadow economy like Ecuador (Medina \& Schneider, 2017), similar life expectancy at birth and low unemployment rates-under 5\% in 2017- (see World Bank, 2017).

We applied the standard methodology for conducting analyses of this nature (see Nikpoor, 2017; CondeRuiz, 2014)—construction of main indicators, such as dependency ratios, population pyramids, employment rates, replacement ratios, and Gini coefficient. Additionally, to determine the characteristics of informality, we ran two logistic regressions to identify the main determinants of work in the informal sector. The data used were collected from various sources, including the National Institute of Statistics and Censuses (Instituto Nacional de Estadística y Censos, INEC, in Spanish), the United Nations, and the Ecuadorian Institute of Social Security (Instituto Ecuatoriano de Seguridad Social, IESS).

Based on the results, we drew two main conclusions: (a) the aging population is not the main source of the PAYG pension systems' financial problems. Even with a good population structure, the presence of financial stress may be explained by low coverage as a consequence of low rates of formal employment; (b) informal employment tends to have more temporary contracts than its formal counterpart. The prevalence of these temporary contracts diminishes with schooling years and age. Therefore, the improvement of education is the main policy lever for enhancing the quality of jobs and consequently, for increasing social security coverage and reducing income inequalities.

The article is structured as follows. Section 2 describes the institutional framework of the Ecuadorian pension system. Section 3 briefly presents the data used. Section 4 presents the findings regarding the dynamics between Ecuador's population and labor market in comparison to other countries. Section 5 discusses the characteristics of informality. Section 6 discusses social security coverage and income inequalities. Finally, Section 7 presents the study's conclusions. 


\section{The Institutional Framework of the Ecuadorian Pension System}

The pension system in Ecuador operates according to a PAYG scheme (Ecuadorian Institute of Social Security, 2014; Organisation for Economic Co-operation and Development-Inter-American Development Bank-World Bank, 2014). It is an aspect of the Social Security managed by the government through the IESS and is based on two tiers: (a) general insurance (IESS insurance) and (b) resource-tested insurance. Our analysis will focus on the first tier, which represents the contributory system.

\subsection{Social Insurance Contributions}

Employees and their employers pay the social security contribution rate. A total contribution rate is $20.60 \%$ applies to all types of insurance: old-age, health, labor risks, and unemployment. Since our focus is on pension system issues, we will concentrate exclusively on old-age insurance, which is split into two groups: (a) old-age only and (b) disability, old-age, and death (IVM, in its Spanish acronym). In 2014, the corresponding total rate for old-age insurance was reduced by four percentage points to fund health insurance, but it is set to increase, expected to reach $10.46 \%$ in 2021 . No ceilings are applied to the wages for the computation of contributions, but pensions have limits (minimum and maximum pensions, which depend on the number of years of contributions; see Tables 1 and 2). In addition to the contributions made by employees and employers, the Social Security Law mandates that the government provide $40 \%$ of benefit expenditures as an instrument for maintaining the financial sustainability of the pension system.

Table 1. Minimum Old-age Pension by Number of Years of Contributions, Ecuador 2010-2017

\begin{tabular}{lccccccccc}
\hline Years of contributions & \% UBS & \multicolumn{7}{c}{ Minimum old-age pension amounts in USD } \\
\cline { 3 - 10 } & & $\mathbf{2 0 1 0}$ & $\mathbf{2 0 1 1}$ & $\mathbf{2 0 1 2}$ & $\mathbf{2 0 1 3}$ & $\mathbf{2 0 1 4}$ & $\mathbf{2 0 1 5}$ & $\mathbf{2 0 1 6}$ & $\mathbf{2 0 1 7}$ \\
\hline \multirow{2}{*}{ up to 10 } & 50 & 120.0 & 132.0 & 146.0 & 159.0 & 170.0 & 177.0 & 183.0 & 187.50 \\
$11-20$ & 60 & 144.0 & 158.4 & 175.2 & 190.8 & 204.0 & 212.40 & 219.60 & 225.0 \\
$21-30$ & 70 & 168.0 & 184.8 & 204.4 & 222.6 & 238.0 & 247.80 & 256.20 & 262.50 \\
$31-35$ & 80 & 192.0 & 211.2 & 233.6 & 254.4 & 272.0 & 283.20 & 292.80 & 300.0 \\
$36-39$ & 90 & 216.0 & 237.6 & 262.8 & 286.2 & 306.0 & 318.60 & 329.40 & 337.50 \\
40 or more & 100 & 240.0 & 264.0 & 292.0 & 318.0 & 340.0 & 354.0 & 366.0 & 375.0 \\
\hline
\end{tabular}

Source: Ecuadorian Institute of Social Security (2017); Jara (2015).

Table 2. Maximum Old-age Pension by Years of Contributions, Ecuador 2010-2017

\begin{tabular}{lccccccccc}
\hline Years of contributions & \% UBS & \multicolumn{7}{c}{ Maximum old-age pension amounts in USD } \\
\cline { 3 - 10 } & & $\mathbf{2 0 1 0}$ & $\mathbf{2 0 1 1}$ & $\mathbf{2 0 1 2}$ & $\mathbf{2 0 1 3}$ & $\mathbf{2 0 1 4}$ & $\mathbf{2 0 1 5}$ & $\mathbf{2 0 1 6}$ & $\mathbf{2 0 1 7}$ \\
& & & & & & & & & \\
\hline $10-14$ & 250.0 & 600.0 & 660.0 & 730.0 & 795.0 & 850.0 & 885.0 & 915.0 & 937.50 \\
$15-19$ & 300.0 & 720.0 & 792.0 & 876.0 & 954.0 & 1020.0 & 1062.0 & 1098.0 & 1125.0 \\
$20-24$ & 350.0 & 840.0 & 924.0 & 1022.0 & 1113.0 & 1190.0 & 1239.0 & 1281.0 & 1312.5 \\
$25-29$ & 400.0 & 960.0 & 1056.0 & 1168.0 & 1272.0 & 1360.0 & 1416.0 & 1464.0 & 1500.0 \\
$30-34$ & 450.0 & 1080.0 & 1188.0 & 1314.0 & 1431.0 & 1530.0 & 1593.0 & 1647.0 & 1687.5 \\
$35-39$ & 500.0 & 1200.0 & 1320.0 & 1460.0 & 1590.0 & 1700.0 & 1770.0 & 1830.0 & 1875.0 \\
40 or more & 550.0 & 1320.0 & 1452.0 & 1608.0 & 1749.0 & 1870.0 & 1974.0 & 2013.0 & 2062.5 \\
\hline
\end{tabular}

Source: Ecuadorian Institute of Social Security (2017); Jara (2015). 


\subsection{Description of Benefit Rules}

\subsubsection{Unemployment}

Unemployment insurance was introduced in 2016. It allows unemployed individuals to receive benefits for up to five months. The requirement for receiving this benefit is to have contributed to the IESS for 24 months, with the six last contributions before unemployment status. However, this insurance does not include contribution payments.

\subsubsection{Pension Benefits}

In Ecuador, the legal age for retirement can begin at age 60 , after a contribution record of at least 30 years (360 contributions). However, if the number of contributions is 480 (40 years), no age restrictions are enforced with respect to retiring and obtaining full pension benefits.

At age 65, a person can receive benefits if they have contributed for at least 15 years (180 contributions) and at age 70 following 10 years of contributions (120 contributions), see Ecuadorian Institute of Social Security (2014).

In the case of uniformed service (army and police), individuals can retire and obtain full pension benefits if they have contributed for 25 years. These contributions and pensions are not managed by the IESS, so we abstract this sector from the others.

An individual's pension benefit for an individual is computed as the mean of the salaries of their best five years (in terms of the highest salaries). Ceilings and floors are applied to the resulting pension benefit. Tables 1 and 2 present the minimum and maximum old-age pensions from 2010 to 2017, respectively. Pensions are based on the minimum wage (Unified Basic Salary, UBS) and the number of contributions made. Note that those limits consist of a range of values in contrast to countries such Spain that operate only one value for the floor and another for the ceiling. The last row of Table 1 represents $100 \%$ of UBS, which permits the observation of the substantial growth in wages from 2010 to 2017 (56.3\%), a high increase in the first years (around 10\%), albeit a decrease in the last annual variations.

When an individual has retired and while they are receiving a pension benefit, they do not pay income tax. However, if they return to work, their pension benefit is stopped and they are restricted to back to the same company or institution and the respective deductions are applied to their new wage.

\section{Data}

The main data sources for our analysis of population and labor market dynamics as well as inequalities were as follows:

- The National Institute of Statistics and Censuses (INEC), which publishes the National Survey of Employment, Unemployment and Subemployment of Ecuador (Encuesta Nacional de Empleo, Desempleo y Subempleo (ENEMDU), Spanish version only).

- The United Nations, which provides data related to population.

- The Ecuadorian Institute of Social Security (IESS), which publishes annual bulletins.

When available, microeconomic data, some from administrative registers, were also used, as indicated below.

\section{Population and Labor Market Dynamics}

This section describes the demographic dynamics in Ecuador over the past six decades as well as projections up to 2060 and 2100 and labor market dynamics from 2007 to 2017

\subsection{Population Dynamics}

The population's composition is determined by three variables: fertility, mortality, and migration. These elements account for the changes in population structure and, as such, it is important to consider them in the analysis.

\subsubsection{Fertility}

In 2015, Ecuador's population was estimated at 16,144 thousand, with a 1.52 percent increase compared to the previous year. However, the average growth rate during the preceding 65 years was $2.39 \%$. These figures clearly show that the country's population growth is decelerating. This is a consequence of declining birth and fertility rates, despite increased life expectancy at birth and at 60 years old and the declining mortality rate. As Figure 1 shows, fertility rates in Ecuador are projected at 2.44 children per woman for the period 2015-2020, in contrast to 1.94 in South America, 1.57 in Spain, and 1.29 in Poland. This indicates that there 
was a sharp decline of $52 \%$ over the last four decades (from 5.05 children per woman) in Ecuador, while in Poland and Spain the decline was less steep, at $42 \%$ and $39 \%$, respectively. The decline in fertility rates in LAC is expected to continue: by 2060, the Ecuadorian rate is projected to be 1.84 in contrast to 1.87 in the other LAC countries. By contrast, the Spanish and Polish rates are expected to increase gradually to 1.82 and 1.63 , respectively.

\subsubsection{Mortality}

Improvements in medicine are allowing people to live for longer, and many countries worldwide have experienced an upward trend in the life expectancy indicator, which is projected to continue as such. In Ecuador, life expectancy at birth has grown by 28 years from 48.65 to 76.67 years old in around six decades (1950-2020). Meanwhile, life expectancy at 60 years has increased by around nine years from 14.68 to 23.47 years. Compared to Poland and South America, Ecuador's population is enjoying longer lifespans (see United Nations, 2017). This phenomenon, among others, will have a financial impact on the pension system. According to Izquierdo et al. (2018), Ecuador and Brazil will see the greatest increase (fourfold) in pension expenditures (including for non-contributors) from 2015 to 2065. However, it should be noted that the Brazilian Senate recently approved some pension system reforms that would significantly reduce pension expenditures, while no such measures have been taken in Ecuador.

\subsubsection{Migration}

Despite the global increase in life expectancy, this indicator is lower in Ecuador than in Spain, which is facing serious problems in relation to its aging population. Fortunately, as Spain is a developed country, the aging problem has been partially resolved by migration flows from developing countries. Ecuadorians currently form one of the main immigrant communities in Spain, many having relocated there following a financial crisis in 1999. Figure 2 shows the evolution of the net effect of migration in Ecuador as well as the natural increase in population (births minus deaths) from 1950 to the present and projections until 2060. In general, Ecuador is characterized as a migrant-sending country, while the net number of migrants was practically null or negative between 1950 and 2015 .
Nevertheless, in recent years, Ecuador has become a receiving nation, leading to a positive estimation of a net total of around 182,000 migrants for the period 2015-2020. This immigration has mainly been impacted by the arrival of Venezuelans, Colombians, and Cubans (see Ledesma, 2019); otherwise, the projection of this indicator would be negative. The net migration flows into Ecuador do not appear to have significantly impacted the pension system. On the contrary, the most important effect stems from the natural increase phenomenon, which is decelerating.

\subsubsection{Population Structure Results: Toward Popula-} tion Aging

\section{Population pyramid}

The three elements analyzed above are reflected in the country's population pyramid. Population age structure is an important determinant of future population dynamics, particularly for PAYG pension systems. Figure 3 shows Ecuador's population age structure as of 1950 and 2017 and predictions for 2050 and 2100. Although younger cohorts remain larger than older groups, the lower birth rate is causing the lower part of the population pyramid to narrow. Comparison between 1950 and 2017 clearly shows the results of the decreasing fertility rate at the base of the pyramid and a slight increase in life expectancy in old age. Projections into the next decades suggest that this trend will continue, creating a "population rectangle" rather than a pyramid.

\section{Dependency ratio}

An important indicator used in pension analysis is the old age "dependency ratio" (DR), namely, the ratio of the number of persons aged 65 years and older to the working age population (i.e., persons aged between 15 and 64). Figure 4 shows the evolution and projections of the old age DR for Ecuador. As the legal retirement age in Ecuador begins at 60 years, we have included another ratio: the number of persons aged 60 years and older to the number of persons aged 15-59 years. Before 1995, these ratios were declining slightly. However, after 1995, the ratios began to increase and are expected to double by 2030 with a sharply upward trend.

Fortunately, this indicator is less severe than in developed countries. For example, the old-age DR con- 


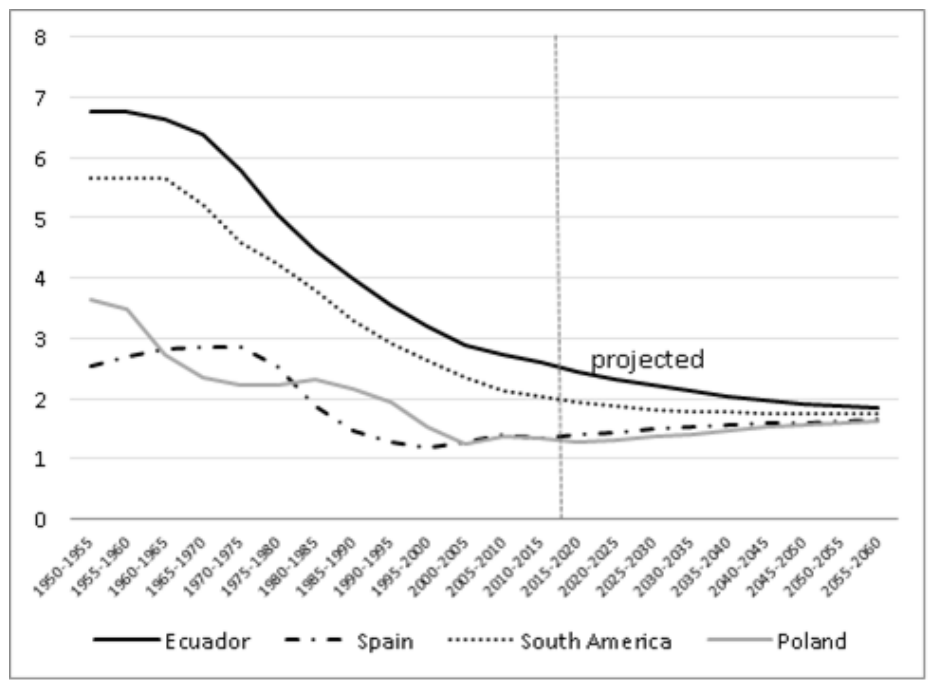

Figure 1. Evolution and projections of the total fertility rate in Ecuador, South America, Spain and Poland, 1950-2060. Source: United Nations (2019)

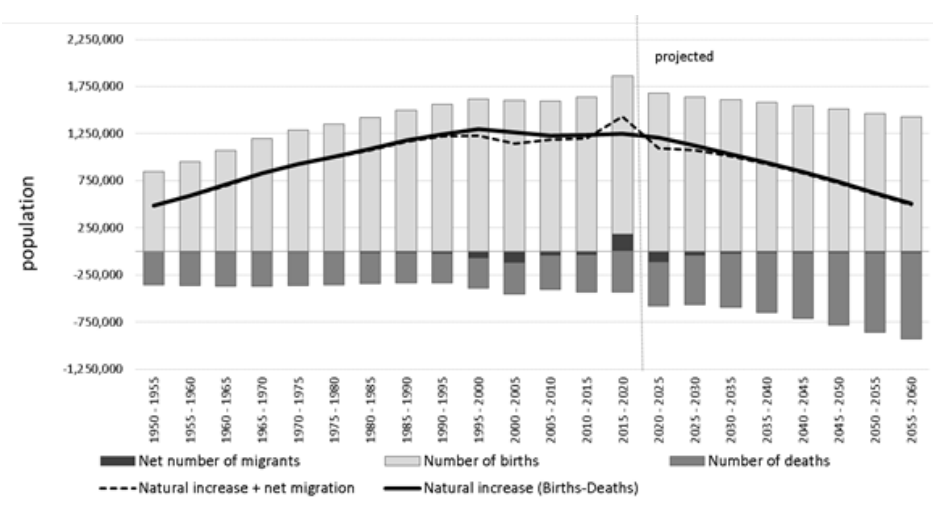

Note: For the sake of clarity in the visualization, the numbers of deaths are presented as negative ones.

Figure 2. Net flow of migrants and natural increase (1950-2060). .

Source: United Nations (2019) 
cerning people aged 60 and over in 2015 (16.26\%) means that for each older adult the economy has 6.15 individuals of working age. This is a positive result for pension systems under the PAYG scheme, in which the pension benefits are provided by the working population. Nevertheless, by 2050 , it is projected to increase to reach $37.05 \%$-that is, 2.7 persons of working age for each older adult (a drop of $44 \%$, which represents a similar decreasing percentage to that of the fertility rate, analyzed above). This situation, associated with low productivity growth, and consequently, with lower economic growth, may give rise to financial stress in the pension system, as is currently happening in Spain (Conde-Ruiz, 2014; De Cos et al., 2018).

\subsection{Labor Market Dynamics}

When analyzing employment issues in Latin American countries, it is necessary to consider the type of employment in question. In Ecuador, the employment indicator has two components: 'adecuado' employment-associated with formal employment due to the positive correlation with income level (see Organisation for Economic Co-operation and Development-Inter-American Development BankWorld Bank, 2014; Bosch et al., 2013; International Labor Organization, 2013)_and 'no adecuado' employment, which is associated with informality. Figure 5 shows the evolution of employment and unemployment rates between 2007 and 2017, offering a first glimpse of low social security coverage.

As shown, the 'adecuado' employment rate has long been below the 'no adecuado' employment rate, with an exception in 2014, when it was 2.37 percentage points higher (47\%). Since then, the 'adecuado' employment rate has decreased until it reached $40.38 \%$ in September 2017, three percentage points lower than in 2007. The unemployment rate has been relatively steady at an average of around $4.8 \%$. Finally, the employment rate, which is the sum of the 'adecuado' and 'no adecuado' employment, was around $62 \%$. Figure 6 presents further details on labor dynamics by gender, within which a substantial labor gap is visible; women typically have lower participation in the labor market ( $51 \%$ on average) than men ( $80 \%$, on average). Likewise, the 'adecuado' or 'no adecuado' employ- ment rates for the case of males are higher than those of females. By and large, however, the gap between both rates is lower for females.

Figure 7 shows the evolution of the employment rate by age group from 2007 to 2017 . It should be noted that around $50 \%$ of those rates constitute 'adecuado' employment. The rate for the population aged 55-64 years declined slowly until 2012 (65.3\%) and then rose to $72 \%$ in 2017. Comparing Ecuador's rate for 2016 (71.8\%) with those of European countries, it was greater than Austria's (51.7\%), Belgium's (51.3.9\%), Finland's (67.8\%), France's (54.9\%), Italy's (55.4\%), and Spain's (59.6\%) (see Figure 14 in the Appendix). Ecuadorians' main motivation in continuing to work into older age partly stems from the country's insufficient insurance provision against labor income risks for the covered population and partly from the low pension insurance coverage and rules governing pension entitlement. Therefore, as we will see below, as only $25 \%$ of the population aged 65 and over has a contributory pension, the employment rate for this sector of the population remains high (around 40\%). The employment rates for the younger (15-24 years old) and older (65 years and over) employed populations are the lowest, while the highest rates are found among individuals aged 35-45.

\section{Characteristics of informality in Ecuador}

The results presented in the previous section provide a detailed review of the situation in the Ecuadorian labor market and an insight into the future problems of the contributory pension system. However, it remains to analyze the factors that are likely to lead to a high degree of informality in Ecuador. The definition of informality used in this study is related to social security coverage, whereby an employed individual is considered to be in "formal" (informal) employment if they are (not) covered (see International Labor Organization, 2013; Bosch et al., 2013).

The primacies of education and contract type as the underlying determinants of employment status means that they should be accounted for in even the most elementary analyses of employment or, indeed, labor force status in general. The higher an in- 

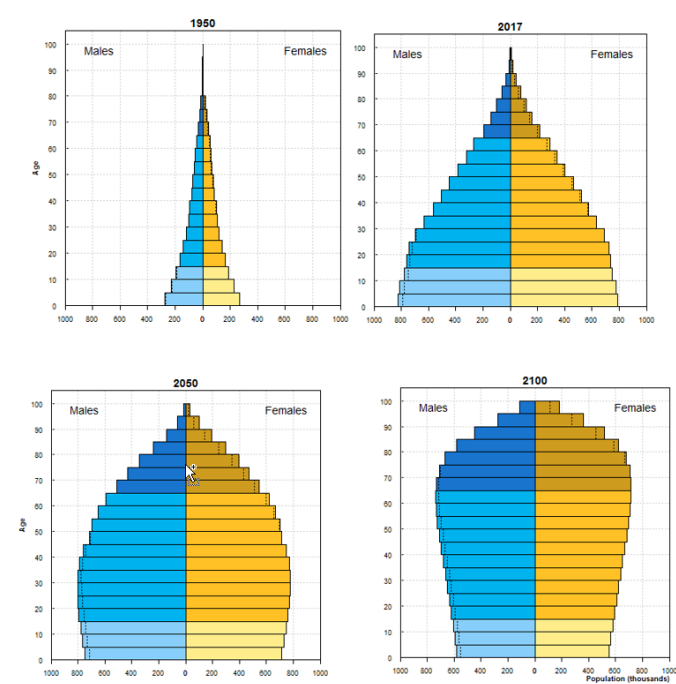

Figure 3. Age Pyramid for Ecuador, 1950, 2017, 2050 and 2100.

Source: United Nations (2019)

Note: The dotted line indicates the excess male or female population in certain age groups. The data are in thousands.

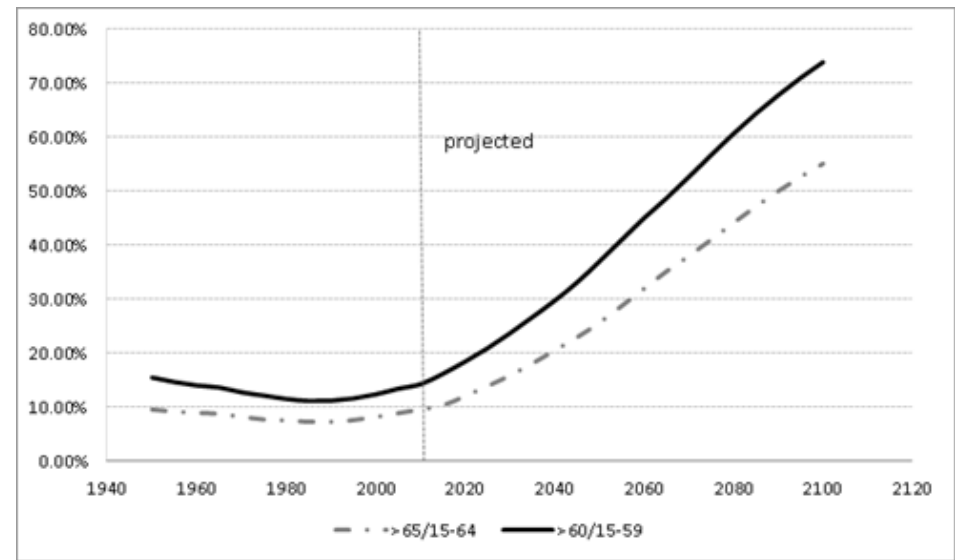

Figure 4. Evolution and projections of the dependency ratio, Ecuador, 1950 to 2100.

Source: Author's calculations from United-Nation (2019) 
dividual's education level, the higher the probability that they will secure formal employment (HerreraIdárraga et al., 2015; Docquier et al., 2017). Moreover, Goldin $(2000 ; 2006)$ shows that dual labor markets impact workers' situations. Finally, earlier research has highlighted demography, geography, and other social factors that can also largely explain employment outcomes: for example, young, female, and indigenous workers are more likely to work in the informal labor market. (Berglund et al., 2017; Goldin, 2000; Goldin, 2006).

To quantify the influence of those variables on informality, we ran two logistic regressions, one for employees with employment contracts (permanent and temporary)-Model 1- and another for selfemployees with no contract-Model 2.

\subsection{Model Variables}

First, we constructed the variable "labor market status". It was created using question No5 in Section 1 of the ENEMDU Survey questionnaire-"Are you insured by?". Thus, we built a dummy variable "insurance", which regrouped the original ten categories into two: (a) insurance and (b) no insurance. Then, the "labor status" variable was divided into four categories using the rule (in brackets): 1 . formal employment (if an individual is employed and has insurance); 2. informal employment (if an individual is employed and has no insurance); 3. unemployment; and 4. inactivity. Table 6 in the Appendix presents the distribution of the labor market status of the Ecuadorian working population (15 years and over) by gender in 2017. A high degree of inactivity is revealed, with females (54.1\%) showing a higher percentage than males (23.9\%), since most housekeepers are women. As expected, a high degree of informality is also evidenced. The share of informal labor in overall employment is 55\%, of which $62 \%$ are male and $38 \%$ female. Women's lower labor participation is also observed in formal employment.

After computing correlations between the variable labor status and several other variables, we found that the main determinants of informality are individuals' contract types and education levels. Other variables also correlated with informality are age, ethnic group, and natural region. Gender has a low correlation with employment status in relation to informality once women's lower participation rate is accounted for.

\subsection{Factors Behind Informal Employment}

The dependent variable of the logistic regression is formal (0) and informal (1) employment condition. Thus,

$\operatorname{Pr}\left(Y=y_{i}\right)=\frac{\exp \left(\eta_{i}\right)}{1+\exp \left(\eta_{i}\right)}, i=1,2, \cdots, n$,

where

$$
Y=\left\{\begin{array}{cc}
1 & \text { Informal Employee } \\
0 & \text { Formal Employee }
\end{array}\right.
$$

$\eta_{i}=\beta_{0}+\beta_{1} X_{i 1}+\cdots+\beta_{k} X_{i k}$, for $k=1,2, \cdots, K$.

and $n$ is the sample size and $X_{K}$ are the independent variables.

The results of the logistic regression model are presented in Table 3. All explanatory variables are both statistically significant and have signs consistent with theory, while the overall model is statistically significant.

\subsubsection{Model 1 Results: Workers with Contracts}

Model 1's results confirm the positive effect of temporary contracts on informality: the odds for workers with temporary contracts are almost 10 times greater than workers with a permanent contract. Regarding age variables, the model confirms that both younger and older workers have a higher probability of being in informal employment. The odds for people aged 15-24 and 55-64 years old are 2.22 and 1 times higher than middle-aged workers (25-54 years old), respectively. Estimations also suggest that indigenous people are more likely than mestizos to be in informal employment. Finally, Model 1's results indicate that higher education has a negative effect on informality. More specifically, the odds for individuals with secondary or higher-level studies are likely to be 0.52 and 0.11 times greater than those with primary studies, respectively. However, this factor has a lower impact than variables such as age or ethnicity. Results pertaining to education may prompt a discussion of how Ecuadorians may secure good jobs (formal employment). Perhaps this might be achieved through friends and relatives, as suggested by Montgomery (1991, p.1408), who observed that individuals who are "well connected might fare better than poorly connected workers". 


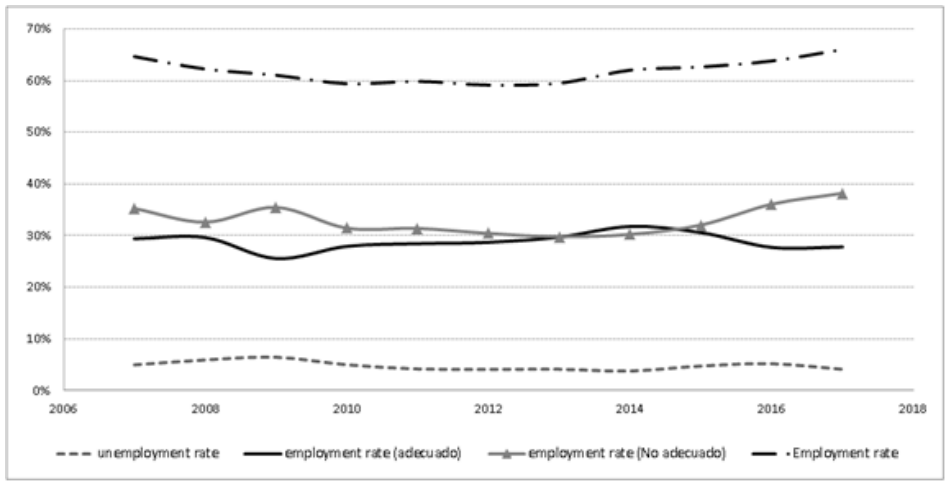

Figure 5. Evolution of employment and unemployment rates, Ecuador 2007 to 2017.

Source: Author's calculations from National Institute of Statistics and Censuses $(2016,2017)$ and ENEMDU data files from 2007 to 2015 available at http://www.ecuadorencifras.gob.ec/banco-de-informacion/

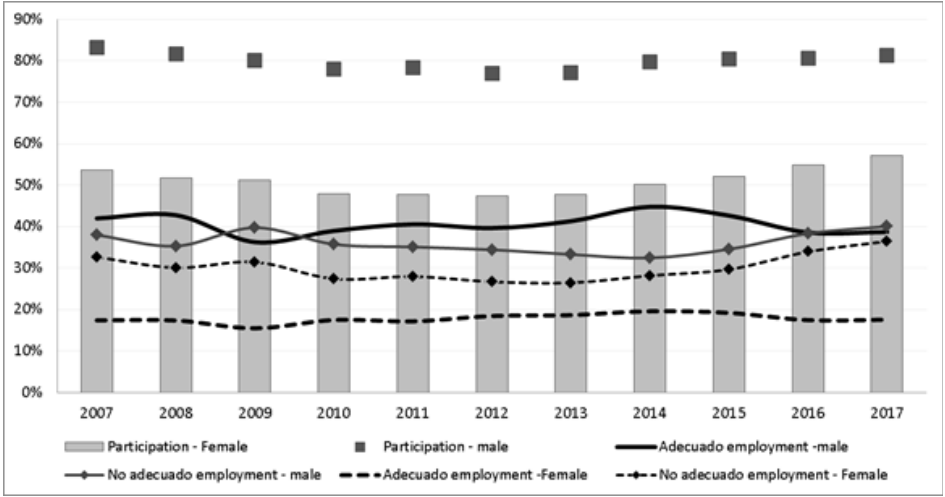

Figure 6. Labor market participation and employment rates by gender (2007-2017).

Source: Author's calculations from ENEMDU data files from 2007 to 2017 available at http://www.ecuadorencifras. gob.ec/banco-de-informacion/ 


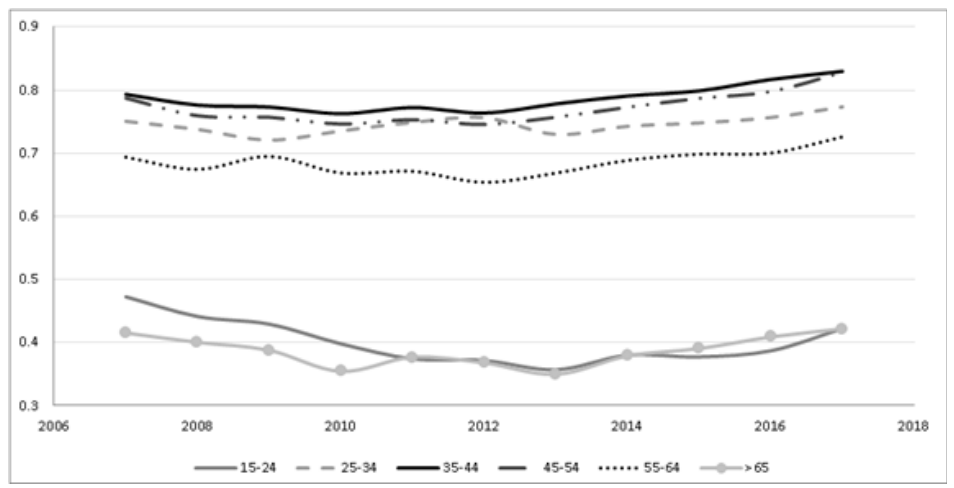

Figure 7. Evolution of employment rate by age groups, Ecuador 2007-2017.

Source: Author's calculations from National Institute of Statistics and Censuses $(2016,2017)$ and ENEMDU data files from 2007 to 2015 available at http://www.ecuadorencifras.gob.ec/banco-de-informacion/

\subsubsection{Model 2 Results: Self-employees.}

The effects of variables on informality in Model 2 are similar to those in Model 1. Nevertheless, as self-employees do not have a contract (which is the main determinant of informality), the odds here (column 7) are higher than those in Model 1 (column 4).

Thus, Model 2's results also confirm the effect of education on formal employment, meaning that a lower education level will lead to a worker being classified as an informal employee. The odds for workers with primary and secondary studies are around three and two times greater than those with higher-level studies, respectively. Regarding age, the odds for self-employees aged 15-24 years is 12 times higher than those aged 65 years and over. This fact, along with the shorter time required for retiring at 65 , may point toward an interesting revelation: Ecuador's self-employees may be implementing a strategy for retiring; that is, individuals may begin to contribute to social security (IESS) at age 50 and retire at 65 -only 15 years-, but they would receive a pension for approximately 12 years. Evidently, this strategy will have a significant impact on the pension system's balance. Having noted the requirements for retirement in Section 2.2.1., it is evident that insufficient incentives exist for contributing to social security (IESS) before the age of 50. For an individual to retire at 60, 30 years of contributions are required, but to retire at 65 they only require 15 years of contributions (i.e., half the time). In future research, we intend to propose a reform of such requirements.

\subsubsection{Profile of Informal Workers}

The simplest way to summarize the major factors underlying informal employment from the estimated results is to examine what happens to the chance of formal employment based on people's various characteristics. The effect of the changes in characteristics are measured relative to a hypothetical reference person (in our case Model 1) who (a) has a permanent contract, (b) has a primary education, (c) is aged $45-56$ or 65 and over, (d) is mestizo by ethnicity, (e) lives in the Amazon region, and (f) is male. The likelihood that a person with the reference characteristics will be an informal worker is $16.14 \%$. If their type of contract is changed to "temporary", c.p., that probability increases 49.22 percentage points up to $65.36 \%$. Moreover, if their education level is improved to secondary level, c.p., that probability is reduced by 7.06 percentage points. 
Table 3. Logistic Regression Results

\begin{tabular}{|c|c|c|c|c|c|c|}
\hline & \multicolumn{3}{|c|}{ Model 1: With contract } & \multicolumn{3}{|c|}{ Model 2: Self-employees } \\
\hline & $\beta$ & Std. Error & $\exp \beta$ (odds) & $\beta$ & Std. Error & $\exp \beta$ (odds) \\
\hline \multicolumn{7}{|c|}{ Type of contract (Permanent) ${ }^{\mathrm{a}}$} \\
\hline Temporary & $2.283^{\star * *}$ & 0.003 & 9.802 & & & \\
\hline \multicolumn{7}{|c|}{ Education level (Primary) $)^{\mathrm{a}}\left(\right.$ Superior) ${ }^{\mathrm{a}}$} \\
\hline Primary & & & & $-1.149^{* * *}$ & 0.004 & 3.154 \\
\hline Secondary & $-.656^{\star * *}$ & .003 & .519 & $-0.851^{* * *}$ & 0.004 & 2.341 \\
\hline Superior & $-2.218^{\star * *}$ & .004 & .109 & & & \\
\hline \multicolumn{7}{|c|}{ Age $(45-54$ and $65+) a(65+) a$} \\
\hline $15-24$ & $0.799^{* * *}$ & .004 & 2.224 & $2.486^{* * *}$ & 0.011 & 12.011 \\
\hline $25-34$ & $0.266^{\star * *}$ & .004 & .587 & $1.528^{\star * *}$ & 0.006 & 4.611 \\
\hline $35-44$ & $0.061^{\star * *}$ & .004 & .478 & $1.070^{* * *}$ & 0.005 & 2.914 \\
\hline $45-54$ & & & & $0.777^{\star * *}$ & 0.005 & 2.176 \\
\hline $55-64$ & $0.014^{* * *}$ & .006 & .1 .014 & $0.359^{* * *}$ & 0.005 & 1.433 \\
\hline \multicolumn{7}{|c|}{ Ethnic groups (Mestizo) ${ }^{\mathrm{a}}(\text { White })^{\mathrm{a}}$} \\
\hline Indigenous & $0.351^{\star * *}$ & .003 & 1.421 & $0.590^{* * *}$ & 0.013 & 1.805 \\
\hline Afro/other & $-.124^{\star \star \star}$ & .004 & .883 & $-0.457^{\star * *}$ & 0.013 & 0.633 \\
\hline White & $0.679^{* * *}$ & .010 & 1.971 & & & \\
\hline Mestizo & & & & $-0.154^{* * *}$ & 0.012 & 0.857 \\
\hline \multicolumn{7}{|c|}{ Region (Amazon)a (Galapagos)a } \\
\hline Andean & $0.137^{\star * *}$ & .007 & 1,147 & $0.304^{* * *}$ & 0.026 & 1,355 \\
\hline Coast & $0.438^{\star * *}$ & .007 & 1,55 & $0.709^{* * *}$ & 0.026 & 2,032 \\
\hline Galapagos & $-.376^{\star * *}$ & .029 & .687 & & & \\
\hline Amazon & & & & $0.482^{* * *}$ & 0.027 & 1.619 \\
\hline \multicolumn{7}{|c|}{ Gender (male)a } \\
\hline Female & $.170^{* * *}$ & .003 & 1,185 & $0.097^{\star * *}$ & 0.003 & 1,102 \\
\hline (Intercept) & $-1.648^{\star \star \star}$ & .008 & .192 & $-0.944^{\star \star \star}$ & 0.029 & 0,389 \\
\hline Sample size & & 24,792 & & & 19,670 & \\
\hline
\end{tabular}

Source: Author's calculations from National Institute of Statistics and Censuses (2017).

a comparison category; ${ }^{* *} p<0.01$. The gender is not a determinant variable for the goodness of fit of the models. However, it helps to keep all estimators significant.

Hosmer \& Lemeshow: $\mathrm{p}=0.000$

In the case of Model 2 (self-employees), the resulting probability that a person with the same characteristics as the benchmark worker of Model 1 (of course, with no contract) will be an informal worker would be $78.75 \%$. A probability gap of 13.39 (62.61) percentage points exists between this type of worker-self-employed - and an employee that has a temporary (permanent) contract. With secondary education, c.p., that probability would decrease by 45.35 percentage points.

\section{Social Security Coverage And Income Inequalities}

Having analyzed the population and labor market dynamics, it is easy to conjecture about the social security coverage situation. In this section, we present information about social security coverage in Ecuador as well as in Latin America and the Caribbean, both for the working-age population (15-64 years old) and for potential retirees (over 65 years old). We also present an analysis of income inequalities among workers and pensioners. 


\subsection{Coverage at Working Age}

\subsubsection{Employed Population with IESS Insurance}

Figure 8 shows the participation of the employed population with the IESS insurance ratio by age groups. This percentage across cohorts increased steadily between 2007 and 2010, fluctuated from 2011 until 2015, and has fallen gradually since 2016 . Note that the percentage of people aged 65 and over did not exhibit such sharp fluctuations as the other cohorts did. Overall, an upward trend was observed in this percentage until 2014, when the trend became downward.

The noticeable increase in this indicator, particularly for those aged $25-34$ years (35.62\% on average), was due to the large increase in public jobs (particularly among highly qualified professionals). Between 2007 and 2017, the government significantly improved public services through the human capital of public employees, whose cost was supported by high oil prices and their revenues to the State General Budget. Moreover, this group of qualified professionals saw a significant increase in wag- es (see Burgos-Dávila \& Falconí-Guamán, 2016), which, of course, had an influence on pension entitlements (replacement rates), as we shall see below. According to Cárdenas-Jaramillo and Roldán-Monsalve (2017), from June 2007 to June 2012 the share of employees in government employment went up 17 percentage points, which corresponds to an average annual growth rate of $3.3 \%$ (the average annual growth rate of the population was $1.6 \%$ in the same period). Likewise, the increase in the ratio of the employed population with IESS insurance across cohorts occurred because more controls were implemented by the Labor Ministry. However, despite this increase, a high proportion of the labor force remained without IESS coverage.

\subsubsection{Coverage at Working Life}

Figure 9 shows the evolution of the social security coverage rate (measured as the number of contributors over the number of working-age population-aged 15-64 years) by gender. Here, it is also evidenced the increasing trend of coverage during the first years (al-

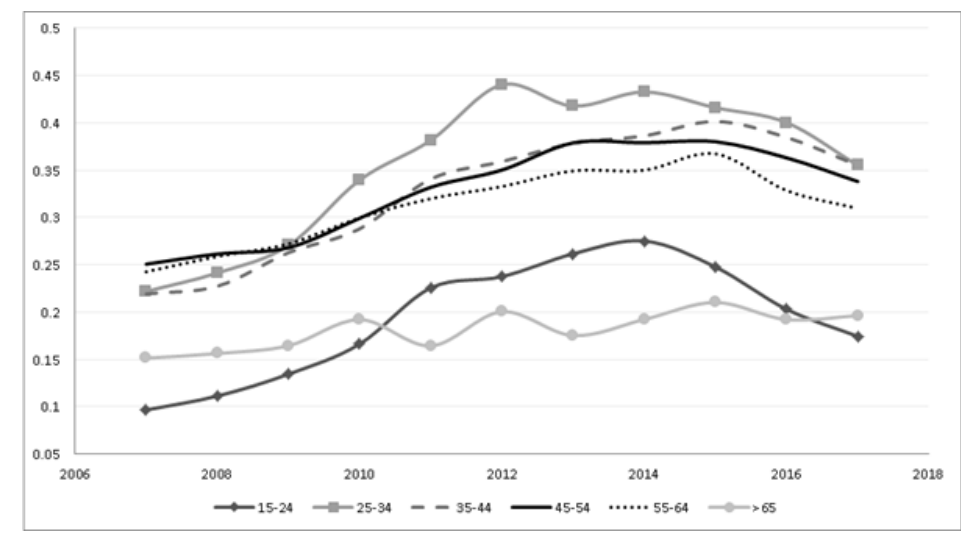

Figure 8. Participation of employed population with IESS insurance ratio by age groups, Ecuador 2007-2017. Source: Author's calculations from National Institute of Statistics and Censuses $(2016,2017)$ and ENEMDU data files from 2007 to 2015 available at http://www.ecuadorencifras.gob.ec/banco-de-informacion/ 
though it is until 2013 instead of 2014) and a descending one in the last years.

Overall, the social security coverage rate rose from $17.88 \%$ to $28.79 \%$ between 2007 and 2015. Despite the increase, a vast gender gap (11 percentage points) is present in the coverage of the working population. The coverage rates for men and women in 2007 and 2015 were $21.78 \%$ and $34.88 \%$ and $14.16 \%$ and $23 \%$, respectively.

Compared to other LAC countries, Ecuador's social security coverage is critical. According to Organisation for Economic Co-operation and DevelopmentInter-American Development Bank-World Bank (2014), Ecuador is one of the LAC countries with the lowest rate of social security coverage (as contributors). Ecuador (30\%) and Paraguay (20\%) have the lowest coverage rates among South American countries with defined-benefit (DB) schemes. Regardless of the pension system schemes, only six countries of the LAC-19 have coverage rates over 50\% (Bosch et al., 2013).

\subsection{Pension System: Coverage and Entitle- ments}

\subsubsection{Pension Coverage}

Since social security coverage is low, contributory pension entitlements remain limited, so that the pension coverage rate among the elderly is also low. In 2015, Ecuadorian pensioners (only old-age insurance) and population over 65 years were 281,119 and 1,126,458, respectively (i.e., only $25 \%$ of the elderly population had a contributory pension). The corresponding growth rates are $7.8 \%$ (for both males and females) and $3.1 \%$ (for males $1.3 \%$ and $4.76 \%$ for women) compared to the previous year.

The pensioner coverage rate, measured as the number of pensioners over 65 years old in the population, has been increasing markedly since 2012. Figure 10 plots this coverage rate from 2007 to 2015 , revealing a significant increase of $89 \%$, from $13 \%$ in 2012 to $25 \%$ in 2015 (the highest rate in the analyzed period). This

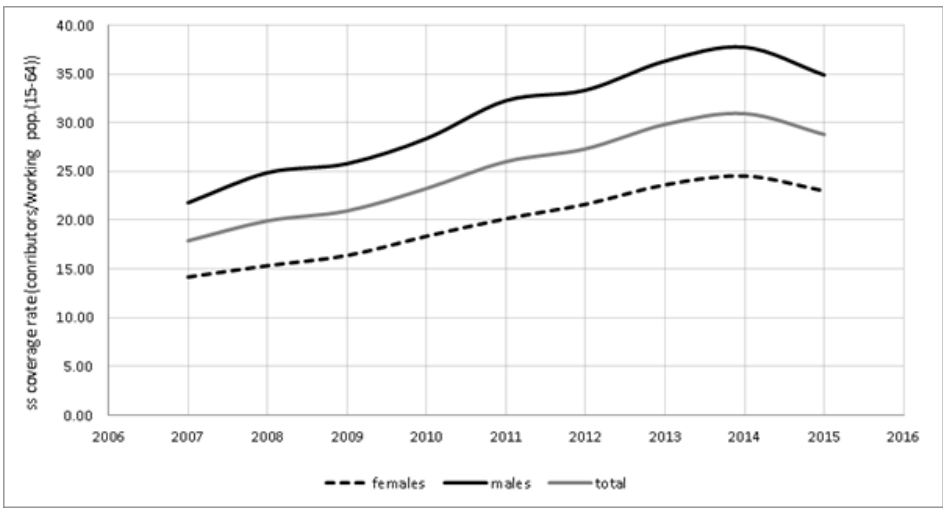

Figure 9. Evolution of contributors as a percentage of working population (aged 15-64 years), 2007-2015 Source: Author's calculation using data from Ecuadorian Institute of Social Security (2007, 2009, 2010, 2013, 2014, 2015) 


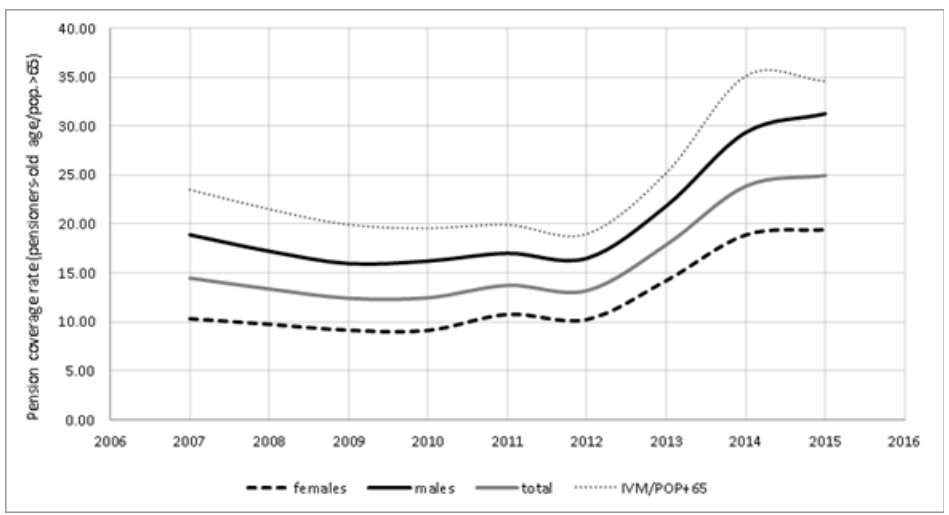

Figure 10. Evolution of the Coverage Rate of Pensioners (Old-age Insurance), 2007-2015.

Source: Author's calculation using data from Ecuadorian Institute of Social Security (2007, 2009, 2010, 2013, 2014, 2015).

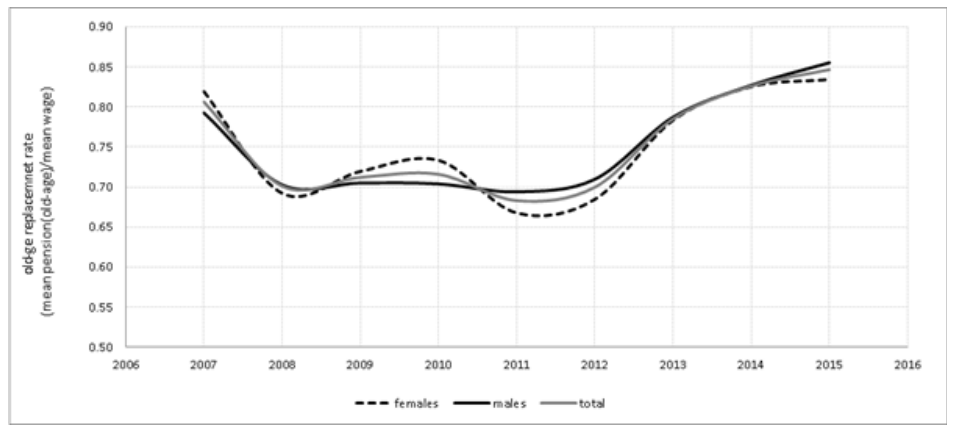

Figure 11. Replacement Ratio (Old-age) by Gender, Ecuador 2007 to 2015.

Source: Author's calculation using data from Ecuadorian Institute of Social Security (2007, 2009, 2010, 2013, 2014, 2015). 
includes the rate for the case of IVM, which of course is higher ( 8 percentage points above the total pension coverage rate).

As shown before, the social security coverage rate (contributors) rose until 2013, when it began to decline. The pension coverage rate from 2012 to 2014 rose by 10.68 percentage points (total) compared with the mere 3.5 percentage points of the social security coverage increase, and consequently, a negative gap of seven percentage points ensued. This situation puts pressure on the pension fund and will continue to exert greater pressure if the number of pensioners continues to rise.

Even by Latin American standards, this coverage rate is rather low. In 2010, Ecuador, jointly with Paraguay, had the lowest percentage of population over 65 years with a contributory pension among South America's countries (Melguizo, 2015).

\subsubsection{Pension entitlements}

The replacement rate (RR)-measured as the average pension benefit of the old-age population over the contributors' average salary-has a direct impact on the financial gap in the pension system, as well as on income inequalities among pensioners and older adults. Figure 11 illustrates its evolution from 2007 to 2015 for old-age insurance by gender.

The RR of old-age insurance has fluctuated, resulting in a drop of 12 percentage points between 2007 (80.23\%) and 2011 (68.31\%). It then rose to peak at 85\% in 2015 and appears to continue growing (at least for males). This fall appears to be a consequence of the tremendous increase in wages. According to Cárdenas-Jaramillo and Roldán-Monsalve (2017), the wages of teachers (as public employees) rose considerably. While in 2007, the mean teachers' wage was USD 309.40 (Ecuadorian Institute of Social Security, 2007), in 2013 it was around USD 900 (USD-2017 675.68) (Ecuadorian Institute of Social Security, 2013). This was the second highest salary among the public workers' mean earnings.

The right axis of Figure 15 in the Appendix shows the promised gross pension RRs for Ecuador, LAC countries and the OECD computed in 2014. The corresponding rate for Ecuador is particularly high $(94.2 \%)$ compared with the average of either the OECD (57\%) or the LAC countries (61.88\%). It is surpassed only by Paraguay.

Table 4. Pension Inequality Coefficients of Contributory Pensioners by Gender (2007, 2017)

\begin{tabular}{|c|c|c|c|c|}
\hline \multirow{2}{*}{$\begin{array}{l}\text { Inequality } \\
\text { coefficient }\end{array}$} & \multicolumn{2}{|c|}{2007} & \multicolumn{2}{|c|}{2017} \\
\hline & Male & Female & Male & Female \\
\hline Gini coefficient & 0.26 & 0.26 & 0.28 & 0.22 \\
\hline
\end{tabular}

available at http://www.ecuadorencifras.gob.ec/banco-de-informacion/

Table 5. Pension Inequality Coefficients of (Contributory and Non-contributory) Pensioners by Gender $(2007,2017)$

\begin{tabular}{lcccc}
\hline $\begin{array}{l}\text { Inequality } \\
\text { coefficient }\end{array}$ & \multicolumn{2}{c}{2007} & & 2017 \\
\cline { 2 - 5 } & Male & Female & Male & Female \\
\hline Gini coefficient & 0.32 & 0.31 & 0.38 & 0.28
\end{tabular}

Source: Author's calculations from National Institute of Statistics and Censuses (2017) and ENEMDU Dec 2007 [data file] available at http://www.ecuadorencifras.gob.ec/banco-de-informacion/ 


\subsubsection{Financial Situation of the Pension System}

High replacement rates, in tandem with a decelerating contributor density and an accelerating pensioner density, will inevitably impact the pension system's financial sustainability. Figure 12 presents the evolution of contribution revenues and pension benefit expenditures from 2012 to 2018 . Note that the negative financial gap from 2015 is explained by a policy reform carried out in 2015, in which the rate of contribution to the pension system was decreased by four percentage points. According to that reform, which also eliminated the subsidy of $40 \%$ of pension expenditures, those gaps were expected to be covered by the pension reserve funds until exhausted, and then the government would finance it. Recently, this measure was derogated, and the government will continue to pay $40 \%$ of contributory pension expenditures with revenues from general taxes; hence, the contributory concept is broken again.

While in 2012, the total expenditures of the contributory pension scheme (benefit payments only) amounted to USD (2007) 1,305 million, or about 2.03\% of the GDP, in 2014, the expenditure of non-contributory benefits made up $0.3 \%$ of the GDP (Bargain, Jara, \& Rodríguez, 2017). This indicates that the government made more transfers (subsidies) to the contributory system $(0.812 \%$ of GDP) than to the non-contributory system that serves individuals that are more vulnerable.

The left axis of Figure 15 in the Appendix shows the shares of pension expenditures in GDP in 2010 and 2015 for Ecuador and some countries of Latin America and the OECD. The average of this share in 2015 for the OECD and LAC countries was $8 \%$ and $3.7 \%$, respectively. In Ecuador, the percentage was the lowest (2.7\% of the GDP), but the growth rate was highest (around $108 \%)$. No variations were noted in Poland, meaning that pension expenditures remained around $11 \%$ of the GDP. In Spain (11\% of the GDP), an increase of 1.9 percentage points (a growth rate of 21\%) was observed.

\subsection{Income Inequalities}

A first glimpse of the elderly income gap in 2015 could be revealed when taking into account the mean of "seguro campesino" (peasant insurance) pension-other regime within the Ecuadorian pension system - that was USD 59.74 versus the mean contributory pensions of USD 545.72 and USD 620.98 for IVM and old-age insurance, respectively. Furthermore, Figure 13 shows that the number of IVM pensioners (left part) and their average pension benefit (right part) by age range in 2014 prompts a second look at the evidence for income inequality among pensioners in Ecuador. It also illustrates that the highest proportion of pensioners are aged 65-69 years, but the highest average benefit is received by those aged 60-64 years. This may prompt a discussion of reforms aimed at increasing the legal age of retirement.

Regarding inequality indicators, Table 4 presents the pension benefit inequality coefficient (Gini) by gender among contributory pensioners. To obtain the sample size, we used data from ENEMDU from December 2007 and 2017. It was assumed that pensioners with lower pensions than $50 \%$ of the minimum wage were non-contributory pensioners (they either receive an assistance-pension or are under "seguro campesino" insurance), and consequently they were excluded from this sample. We found that this cohort accounts for $26 \%$ of the pension inequality among contributory pensioners in 2007. In 2007, no evidence of a contributory pension inequality gender gap was found. However, it emerged in 2017, when the male Gini index (28\%) was six percentage points higher than the female index. It is noteworthy that pension inequality among women has declined.

When non-contributory pensioners are included, the inequality index is higher as expected (see Table 5). Here, the same patron is observed (i.e., comparing indexes between years); they have increased in for males, unlike for females.

Although the inequality among pensioners is "low", it is partly so because of non-contributory pensions and partly because of low-income levels.

\section{Discussion, conclusions, and policy recommendations}

We have reviewed the current state of the population structure and labor market and their interlinkages with pension systems (focusing primarily on the contributory pension) in Ecuador (a country with a high degree of informality). We also examined the characteristics of informality in Ecuador as well as income inequalities among older adults. The results demand urgent reforms in labor institutions and pension systems, many of which have already been suggested by Barr and Diamond, (2009); Hinz et al. (2012); Melguizo et al., (2017); and Organisation for Economic Co-operation and De- 


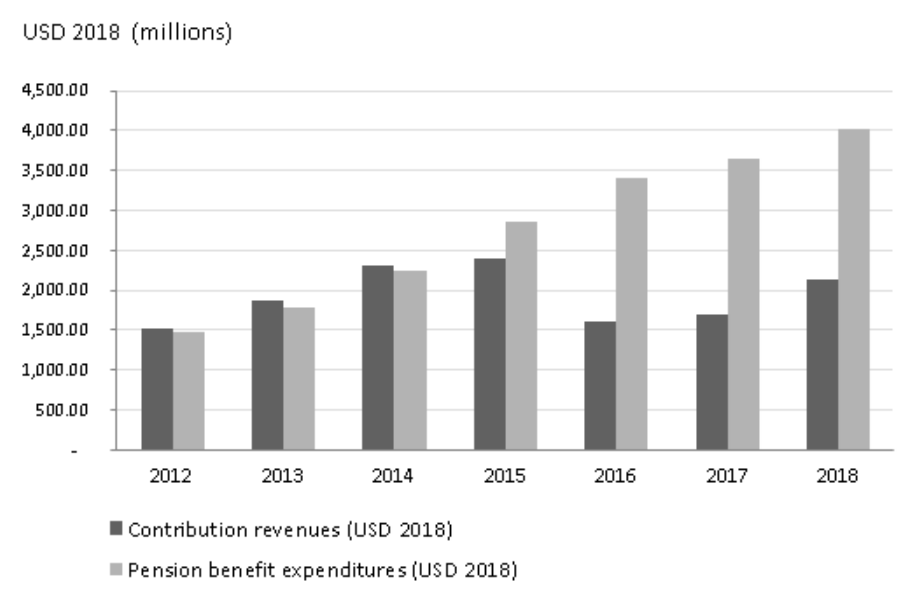

Figure 12. Contribution Revenues and Pension Benefit Expenditures, 2012-2018.

Source: Author's calculations from Transparencia Fiscal No.143: Julio 2018 [Taxation Transparency № 143: July 2018], available at https://www.observatoriofiscal.org/; and IESS Resolutions (CD: 402, 441, 461, 475, 507, 545, and 567), available at https://www.iess.gob.ec/es/resoluciones/.

velopment-Inter-American Development Bank-World Bank, (2014) among others. However, as Fatás (2015, p.34) mentioned, a "reform is ultimately a domestic political business where trade-off are being made between economic efficiency, social goals and the way power and income are distributed in a society", this article aims to be an instrument of support for policy makers in the Ecuadorian economy. Since the pensioners do not now represent a significant percentage of potential voters, as is the case in European countries (Conde-Ruiz, 2014), pension reforms may be politically manageable. Otherwise, in the context of Latin America, "in the coming decades, adults aged 65 and over will make up between $20 \%$ and $30 \%$ of the potential electorate of the region, so their needs will be decisive in electing governments" (Melguizo et al., 2017, p. 125).

Hence, the results were used to derive the following major conclusions, policy recommendations, and further research approaches.

First, in Ecuador (a country that operates a PAYG pension system), the aging population is not the main source of the pension system's financial problems. Even with a good population structure, the financial stress ap- pears to be attributable to low social security coverage as a consequence of low formal employment rates. In 2015, only $25 \%$ of people aged 65 years and over had a contributory pension. However, if no reforms are implemented with the long-term situation in mind, the situation will worsen when Ecuador's population indicators become identical to those of Europe.

Second, the public contributory pension system of Ecuador (a developing country) is characterized by a high level of generosity. Its replacement rate $(94.2 \%$ in 2014 ) is superior to the average of the OECD countries (57\%). Nevertheless, a high level of poverty and income inequality among older people would evidence the existence of a poor policy of income redistribution. This highlights the need for changes in pension entitlements; thus, in future research, we will study the intra-generational inequalities within the current pension system and some alternative systems.

Third, that the Ecuadorian pension system is facing a negative financial gap up from 2015, which seems to keep growing due to the upward trend in the pension coverage rate and the downward trend (from 2013) in the social security coverage rate. Although this gap is 


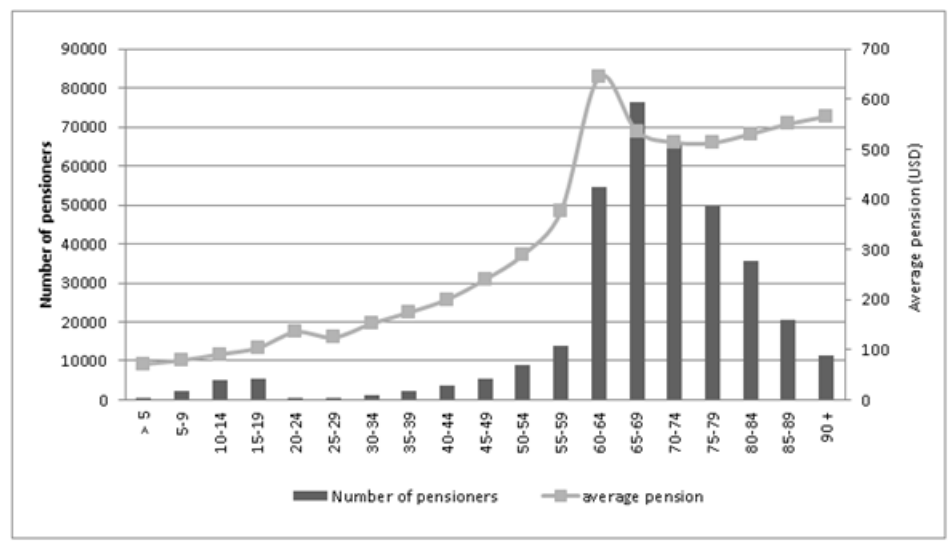

Figure 13. Number of IVM Pensioners and Average Pensions by Age Range, 2014.

Source: Author's calculation using data from Ecuadorian Institute of Social Security (2014).

financed, in part, by the government (the governmentfinanced share of the contributory pension benefit expenditures is equal to $40 \%$ ), it would be insufficient to cover that difference in the future. Thus, to increase the number of contributors (thereby increasing social security coverage), and in line with Melguizo et al. (2017), it could be used to subsidize the contribution rate rather than the pension benefits. Since that type of policy has a clear impact on the economy, it should be explored in future research.

Fourth, aside from that gap, an upward trend was observed in the social security coverage of the labor force between 2007 and 2013, motivated by a large increase in public employment as a consequence of high oil prices and their revenues to the government's budget of government. Nevertheless, it has not been enough to improve the 'adecuado' employment rate and consequently surpasses at least $50 \%$ of the employees' social security coverage. Of course, this analysis has taken place in an isolated context; it remains to quantify the effects on the workers' welfare. As Melguizo et al. (2017) mentioned, these results attest the weakness of the Ecuadorian economy as a country whose budget depends on commodi- ties. Bad jobs contribute to large income inequalities among the working population (even Ecuador is "not so bad" as Brazil, Colombia, or Panama), with women more affected than men, as well as the younger and older (55-64 year-old) workers. Among other factors, this situation has established a high level of informality, the most prominent feature (besides low coverage) of which is the lack of quality in jobs-high levels of temporary contracts, low wage levels, and a large share of self-employed workers or enterprise owners. Additionally, the results reveal that lower schooling levels contribute to increased informal employment; and in view of low female labor participation rates, it may be said that males are the main economic providers in Ecuadorian households. Consequently, Ecuador should implement policy reforms that reverse the 'no adecuado' employment rates. Endeavors to improve jobs should take into account these particularities but also new labor market challenges, such as automation and innovation, which may further disrupt the labor market (i.e., the fall in labor demand) (Jimeno, 2019; Filgueira \& Manzi, 2017). Moreover, new policies should be accompanied by the establishment of a culture of savings and pensions 
through financial education. This would allow the introduction of more profound pension reforms in the future. Finally, since Ecuador has almost a null unemployment benefit coverage and to guarantee workers' contribution records (now it is left on behalf of the beneficiary), the reform of unemployment insurance is also recommended.

In conclusion, our analysis has focused on the contributory pension system ('general insurance') as distinct from voluntary and "seguro campesino" insurance. However, these were included in the analysis of the pensioners' coverage, entitlements, and inequalities, and in comparing LAC countries (although they have not been cited specifically). Therefore, the broad overview of informality and policy recommendations will hardly be changed. We will address some of the questions raised in this paper in future studies.

\section{References}

Arenas de Mesa, A. (2019). Los sistemas de pensiones en la encrucijada: desafíos para la sostenibilidad en América Latina [Pension systems at the crossroads: challenges for sustainability in Latin America]. Comisión Económica para América Latina y el Caribe.

Bargain, O., Jara, H. X., \& Rodríguez, D. (2017). Learning from your neighbor: Tax-benefit systems swaps in Latin America. Journal of Economic Inequality, 15(4), 369392. https://doi.org/10.1007/s10888-017-9367-5

Barr, N., \& Diamond, P. (2009). Reforming pensions: Principles, analytical errors and policy directions. International Social Security Review, 62(2), 5-29. https://doi. org/10.1111/j.1468-246X.2009.01327.x

Berglund, T., Håkansson, K., Isidorsson, T., \& Alfonsson, J. (2017). Temporary employment and the future labor market status. Nordic Journal of Working Life Studies, 7(2). https://doi.org/10.18291/njwls.v7i2.81593

Blake, D. (2006). Pension Economics. John Wiley \& Sons.

Bosch, M., Melguizo, A., \& Pagés, C. (2013). Better Pensions, Better Jobs: Towards Universal Coverage in Latin America and the Caribbean. Inter-American Development Bank.

Burgos-Dávila, S., \& Falconí-Guamán, G. (2016). Schooling on young workers' wages: the Ecuadorian case. Revista Economía y Política, (23), 25-37. https://doi. org/10.25097/rep.n23.2016.02

Cárdenas-Jaramillo, P., \& Roldán-Monsalve, D. (2017). El impacto del servicio público en el mercado laboral: Evidencia temprana del efecto de la política pública de contratación sobre el mercado laboral en el Ecuador en el período 2001-2010 [The impact of the public service in the labor market: Early evidence of the effect of the public policy of contracting on the Labor Market in Ecuador in the period 2001-2010]. Revista Economía y Politica, (24), 93-116. https://doi.org/10.25097/rep. n24.2016.04

Conde-Ruiz, J. I. (2014). ¿Qué será de mi pensión?: Cómo hacer sostenible nuestro futuro como jubilados [What will become of my pension? How to make our future as retirees sustainable]. Grupo Planeta Spain.

Conde-Ruiz, J. I., \& González, C. I. (2010). Envejecimiento: Pesimistas, optimistas, realistas [Aging: Pessimistic, optimistic, realistic]. Panorama Social, 1, 112-133.

Conde-Ruiz, J. I., \& González, C. I. (2016). From Bismarck to Beveridge: The other pension reform in Spain. SERIEs, 7(4), 461-490. https://doi.org/10.1007/s13209-0160148-3

De Cos, P. H., Ramos, R., \& Jimeno, J. F. (2018). The Spanish public pension system: The quest for financial sustainability and equity. Revista de Economía Aplicada, 26(76), 133-156.

Docquier, F., Müller, T., \& Naval, J. (2017). Informality and long-run growth. The Scandinavian Journal of Economics, 119(4), 1040-1085. https://doi.org/10.1111/ sjoe. 12185

Ecuadorian Institute of Social Security. (2007). Boletín Estadístico [Statistical Bulletin] No.16: 2006-2007. Retrieved 15 November 2017 from https://www.iess.gob. ec/es/web/guest/estadisticas

Ecuadorian Institute of Social Security. (2009). Boletín Estadístico [Statistical Bulletin] No.17: 2008-2009. Retrieved 15 November 2017 from https://www.iess.gob. ec/es/web/guest/estadisticas

Ecuadorian Institute of Social Security. (2010). Boletín Estadístico [Statistical Bulletin] No.18: 2010. Retrieved 15 November 2017 from https://www.iess.gob.ec/es/web/ guest/estadisticas

Ecuadorian Institute of Social Security. (2013). Boletín Estadístico [Statistical Bulletin] No.19: 2011-2013. Retrieved 15 November 2017 from https://www.iess.gob. ec/es/web/guest/estadisticas

Ecuadorian Institute of Social Security. (2014). Boletín Estadístico [Statistical Bulletin] No.20: 2014. Retrieved 15 November 2017 from https://www.iess.gob.ec/es/web/ guest/estadisticas

Ecuadorian Institute of Social Security. (2015). Boletín Estadístico [Statistical Bulletin] No.21: 2015. Retrieved 15 October 2018 from https://www.iess.gob.ec/es/web/ guest/estadisticas

Fatás, A. (2015). The agenda for structural reform in Europe. CEPR Discussion Papers 10723. https://cepr.org/active/ publications/discussion_papers/dp.php?dpno=10723,

Filgueira, F., \& Manzi, P. (2017). Pension and income trans- 
fers for old age: Inter- and intra-generational distribution in comparative perspective. Serie Politicas Sociales 225. ECLAC.

Goldin, C. (2000). Labor markets in the twentieth century. In S. L. Engerman and R. E. Gallman, (Eds.), The Cambridge Economic History of the United States, Vol. 3, (549-624). Cambridge University Press.

Goldin, C. (2006). The quiet revolution that transformed women's employment, education, and family. American Economic Review 96(2), 1-21. https://doi.org/10.1257/0 00282806777212350

Herrera-Idárraga, P., López-Bazo, E., \& Motellón, E. (2015). Double penalty in returns to education: Informality and educational mismatch in the Colombian labour market. The Journal of Development Studies, 51(12), 1683-1701, https://doi.org/10.1080/00220388.2015.1041516

Hinz, R., Holzmann, R., Takayama, N., \& Tuesta, D. (2012). Matching defined contributions schemes: Role \& limits to increase coverage in low and middle income countries. World Bank.

International Labor Organization (2013). Women \& men in the informal economy: A statistical picture (second edition). International Labor Organization Geneva.

Izquierdo, A., Pessino, C., \& Vuletin, G. (2018). Mejor gasto para mejores vidas: cómo América Latina y el Caribe puede hacer más con menos [Better spending for better lives: How Latin America and the Caribbean can do more with less]. Inter-American Development Bank.

Jara, H. X. (2015). Tax-benefit microsimulation in Ecuador: A feasibility study (WIDER Working Paper No. 2015/128). World Institute for Development Economics Research. https://doi.org/10.35188/UNU-WIDER/2015/017-1

Jimeno, J.F. (2019). Fewer babies and more robots: Economic growth in a new era of demographic and technological changes. SERIEs, 10(2), 93-114. https://doi.org/10.1007/ s13209-019-0190-Z.

Ledesma, N. (2019). Ecuador migration trends. The Dialogue. https://www.thedialogue.org/analysis/ecuador-migration-trends/

Medina, L., \& Schneider, F. (2017). Shadow economies around the world: New results for 158 countries over 1991-2015 (Working Paper No. 6430). CESifo. https://ssrn.com/abstract=2965972, Accessed 10 January 2018.

Melguizo, A. (2015). Pensions, informality and the emerging middle class. IZA World of Labor, 169, 1-10. https://doi. org/10.15185/izawol.169.

Melguizo, A., Bosch, M., \& Pages, C. (2017). Better pensions, better jobs: Status and alternatives toward universal pension coverage in Latin America \& the Caribbean. Journal of Pension Economics \& Finance, 16(2), 121-143. https:// doi.org/10.1017/S1474747215000190

Montgomery, J. D. (1991). Social networks and labor-market outcomes: Toward an economic analysis. The American Economic Review, 81(5), 1408-1418. http://www.jstor. org/stable/2006929

National Institute of Statistics and Censuses, Ecuador (2016). Encuesta Nacional de Empleo, Desempleo y Subempleo, Dic 2016. [National Survey of Employment, Unemployment and Subemployment, Dec 2016] [Data set]. Retrieved 15 November 2017 from http://www.ecuadorencifras.gob.ec/banco-de-informacion/

National Institute of Statistics and Censuses, Ecuador (2017). Encuesta Nacional de Empleo, Desempleo y Subempleo, Sep 2017. [National Survey of Employment, Unemployment and Subemployment, Sep 2017] [Data set]. Retrieved 15 November 2017 from http://www.ecuadorencifras.gob.ec/banco-de-informacion/

Nikpoor, S. (2017). Three Essays on Modeling Aging Population [Doctoral dissertation University of Ottawa]. uO Research. http://dx.doi.org/10.20381/ruor-20713

Organisation for Economic Co-operation and Development (2015). Pensions at a Glance 2015: OECD \& G20 indicators. OECD. https://doi.org/10.1787/pension_glance2015-en

Organisation for Economic Co-operation and Development (2016). OECD Factbook 2015-2016: Economic,Environmental and Social Statistics. OECD.

Organisation for Economic Co-operation and Development (2017). Preventing Ageing Unequally. OECD. https://doi. org/10.1787/factbook-2015-en

Organisation for Economic Co-operation and Development (2019), Labour force participation rate (indicator). https://doi.org/10.1787/8a801325-en (Accessed 15 December 2019)

Organisation for Economic Co-operation and DevelopmentInter-American Development Bank-World Bank. (2014). Pensions at a Glance: Latin America and the Caribbean. OECD. https://doi.org/10.1787/pension_glance-2014-en

Peeters, M. (2012). Better safe than sorry: Individual risk-free pension schemes in the European Union. Contemporary Economics, 6(3), 22-37. https://doi.org/10.5709/ce.18979254.48

United Nations (2017). World Population Prospects: The 2017 Revision. [Data set]. Retrieved 15 November 2017 from https://population.un.org/wpp/Graphs/DemographicProfiles/Pyramid/218

United Nations (2019). World Population Prospects: The 2019 Revision. [Data set]. Retrieved 15 February 2020 from https://population.un.org/wpp/Download/Standard/ Population/

World Bank (2017). Databank, World Development Indicators. [Data Set] Retrieved 10 March 2018 from https:// databank.worldbank.org/source/world-developmentindicators 


\section{Appendix}

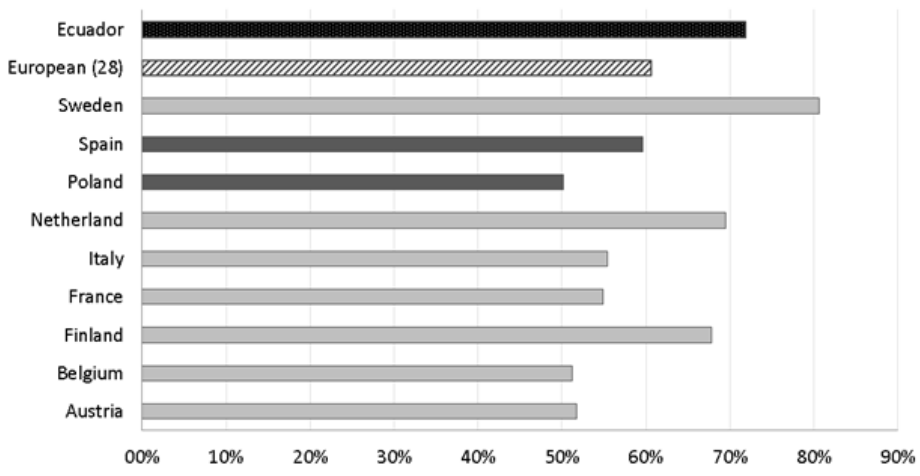

Figure 14. Labor Market Participation Rate (55-64-year-olds, \% in same group, 2016).

Source: Author's calculations from ENEMDU data files of 2016, available at http://www.ecuadorencifras.gob.ec/

banco-de-informacion/; Organisation for Economic Co-operation (2019)

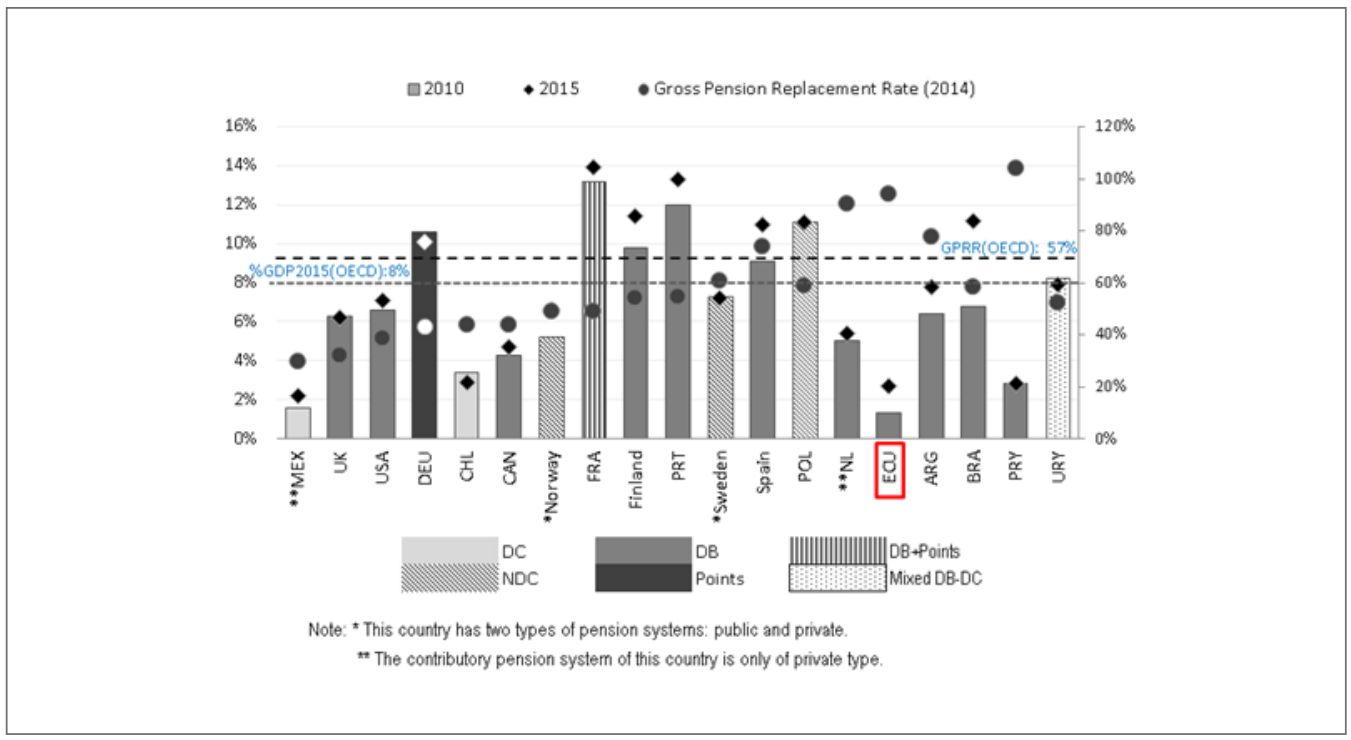

Figure 15. Shares of Pension Expenditures in GDP in 2010 and 2015 (left axis) and Gross Pension Replacement Rates (average earners), around 2014 (right axis) for Ecuador, several Latin American countries, and the OECD.

Source: Organisation for Economic Co-operation and Development-Inter-American Development Bank-World Bank. (2014); Arenas de Mesa (2019). 
Table 6. Distribution of Ecuadorian Working Population (Aged 15 Years and Over) by Labor Market Status and Gender, 2017.

\begin{tabular}{|c|c|c|c|c|c|c|}
\hline \multirow[t]{2}{*}{ Labor Marker status } & \multicolumn{2}{|c|}{ Male } & \multicolumn{2}{|c|}{ Female } & \multicolumn{2}{|c|}{ Total } \\
\hline & Freq. & $\%$ & Freq. & $\%$ & Freq. & $\%$ \\
\hline Formal & $1,904,885$ & 32.9 & $1,181,992$ & 19.2 & $3,086,877$ & 25.9 \\
\hline Informal & $2,334,750$ & 40.3 & $1,436,900$ & 23.4 & $3,771,650$ & 31.6 \\
\hline Unemployment & 166,975 & 2.9 & 205,429 & 3.3 & 372,404 & 3.1 \\
\hline Inactive & $1,380,794$ & 23.9 & $3,326,203$ & 54.1 & $4,706,997$ & 39.4 \\
\hline Total & $5,787,405$ & 100.0 & $6,150,524$ & 100.0 & $11,937,928$ & 100 \\
\hline
\end{tabular}

Source: Author's calculations from National Institute of Statistics and Censuses (2017). 